\title{
Effects of Prepubertal or Adult Site-Specific Knockdown of Estrogen Receptor $\beta$ in the Medial Preoptic Area and Medial Amygdala on Social Behaviors in Male Mice ${ }^{1,2,3}$
}

\author{
Mariko Nakata, ${ }^{1}$ Kazuhiro Sano, ${ }^{1}$ Sergei Musatov, ${ }^{2,+}$ - Naoko Yamaguchi, ${ }^{3}$ Toshiro Sakamoto, ${ }^{4}$ and \\ (1) Sonoko Ogawa ${ }^{1}$
}

\section{DOI:http://dx.doi.org/10.1523/ENEURO.0155-15.2016}

${ }^{1}$ Laboratory of Behavioral Neuroendocrinology, University of Tsukuba, Tsukuba, Ibaraki 305-8577, Japan, ${ }^{2}$ Laboratory of Molecular Neurosurgery, Weill Cornell University Medical College, New York, New York 10021, ${ }^{3}$ Department of Pharmacology, School of Medicine, Aichi Medical University, Nagakute, Aichi 480-1195, Japan, and ${ }^{4}$ Department of Psychology, Kyoto Tachibana University, Kyoto, Kyoto 607-8175, Japan

\begin{abstract}
Testosterone, after being converted to estradiol in the brain, acts on estrogen receptors (ER $\alpha$ and $E R \beta)$ and controls the expression of male-type social behavior. Previous studies in male mice have revealed that ER $\alpha$ expressed in the medial preoptic area (MPOA) and medial amygdala (MeA) are differently involved in the regulation of sexual and aggressive behaviors by testosterone action at the time of testing in adult and/or on brain masculinization process during pubertal period. However, a role played by $\operatorname{ER} \beta$ in these brain regions still remains unclear. Here we examined the effects of site-specific knockdown of ER $\beta$ ( $\beta E R K D)$ in the MPOA and MeA on male social behaviors with the use of adeno-associated viral mediated RNA interference methods in ICR/Jcl mice. Prepubertal $\beta E R K D$ in the MPOA revealed that continuous suppression of ER $\beta$ gene expression throughout the pubertal period and adulthood decreased aggressive but not sexual behavior tested as adults. Because $\beta$ ERKD in the MPOA only in adulthood did not affect either sexual or aggressive behaviors, it was concluded that pubertal $\mathrm{ER} \beta$ in the MPOA might have an essential role for the full expression of aggressive behavior in adulthood. On the other hand, although neither prepubertal nor adult $\beta$ ERKD in the MeA had any effects on sexual and aggressive behavior, $\beta E R K D$ in adulthood disrupted sexual preference of receptive females over nonreceptive females. Collectively, these results suggest that $\mathrm{ER} \beta$ in the MPOA and MeA are involved in the regulation of male sexual and aggressive behavior in a manner substantially different from that of ER $\alpha$.
\end{abstract}

Key words: aggressive behavior; estrogen receptor $\beta$; medial amygdale; medial preoptic area; sexual preference; site-specific knockdown

\section{Significance Statement}

We investigated the role played by estrogen receptor $\beta(E R \beta)$ expressed in the medial preoptic area (MPOA) and medial amygdala (MeA) in the regulation of male-type social behaviors with the use of RNA interference methods for brain site-specific ER $\beta$ knockdown ( $\beta E R K D)$ in mice. We found that ER $\beta$ in the MPOA might be necessary for testosterone to fully masculinize the aggressive, but not sexual, behavior neural network through organizational action during the pubertal period. On the other hand, ER $\beta$ in the MeA may be involved in sexual information processing because $\beta$ ERKD male mice failed to show sexual preference toward a receptive female over a nonreceptive female. These finding are greatly contrasted with previously reported functions of $\mathrm{ER} \alpha$. 


\section{Introduction}

Gonadal steroid hormones play an essential role in the regulation of social behaviors. In male mice, testosterone is known to be indispensable for a series of male-type social behaviors. Testosterone is mainly secreted from the testes into the blood stream and binds either to androgen (AR) or estrogen (ER) receptors, after conversion to estradiol by aromatase in the brain.

Two subtypes of $\mathrm{ERs}, \mathrm{ER} \alpha$ and $\mathrm{ER} \beta$, are known to mediate intracellular actions by aromatized testosterone. Previous studies have reported that $\mathrm{ER} \alpha$ and $\mathrm{ER} \beta$ may play different roles in the regulation of male social behavior. $\mathrm{ER} \alpha$ is necessary for induction, because systemic knock-out of $\mathrm{ER} \alpha(\alpha \mathrm{ERKO})$ in male mice caused severe deficits in sexual and aggressive behaviors (Ogawa et al., 1997, 1998, 2000; Rissman et al., 1997; Wersinger et al., 1997). On the other hand, ER $\beta$ may play a modulatory role on the expression of these behaviors. It is reported that $\mathrm{ER} \beta$ knock-out ( $\beta \mathrm{ERKO}$ ) mice show increased levels of aggressive behavior depending on age and social experiences (Ogawa et al., 1999; Nomura et al., 2002, 2006), hyper-reactivity to social stimuli (Handa et al., 2012; Tsuda et al., 2014), altered risk-taking behavior (Kavaliers et al., 2008) and increased levels of anxiety (Walf and Frye, 2006; Weiser et al., 2008; Tomihara et al., 2009; Oyola et al., 2012).

$\mathrm{ER} \alpha$ and $\mathrm{ER} \beta$ are expressed in several brain regions in the limbic and hypothalamic regions (Shughrue et al., 1997; Mitra et al., 2003), which are main components of the social behavior neural network (Newman, 1999; Nelson and Trainor, 2007; Hull and Rodriguez-Manzo, 2009). Although there are brain areas expressing primarily ER $\alpha$ [eg, hypothalamic ventromedial nucleus (VMN)] or ER $\beta$ (eg, hypothalamic periventricular nucleus, midbrain dorsal raphe), a number of regions such as the medial preoptic area (MPOA) and medial amygdala (MeA) are known to express both types of ERs. In a recent study, achieved site-specific knockdown of $\mathrm{ER} \alpha(\alpha \mathrm{ERKD})$ in adult (16 weeks of age) male mice using adeno-associated viral vector (AAV)-mediated RNA interference (RNAi), lack of $\mathrm{ER} \alpha$ in the VMN reduced both of sexual and aggressive

Received December 15, 2015; accepted March 15, 2016; First published March 23, 2016.

${ }^{1}$ The authors report no conflict of interest.

${ }^{2}$ Author contributions: M.N., K.S., S.M., N.Y., T.S., and S.O. designed research; M.N., K.S., and N.Y. performed research; S.M. and S.O. contributed unpublished reagents/analytic tools; M.N. and K.S. analyzed data; M.N., K.S., and S.O. wrote the paper.

${ }^{3}$ This work was supported by grant-in-aid for Scientific Research 23240057 and $15 \mathrm{H} 05724$ to S.O.; M.N. was a recipient of the Japan Society for Promotion of Science research fellowship for young scientists. The authors thank $\mathrm{Dr}$ C. Pavlides for reviewing the paper.

tDeceased on May 2015.

Correspondence should be addressed to Dr Sonoko Ogawa, Laboratory of Behavioral Neuroendocrinology, University of Tsukuba, Research Building D-409, 1-1-1 Tennodai, Tsukuba, Ibaraki 305-8577, Japan. E-mail: ogawa@kansei.tsukuba.ac.jp.

DOI:http://dx.doi.org/10.1523/ENEURO.0155-15.2016

Copyright @ $2016 \quad$ Nakata et al.

This is an open-access article distributed under the terms of the Creative Commons Attribution 4.0 International, which permits unrestricted use, distribution and reproduction in any medium provided that the original work is properly attributed. behaviors, whereas, ER $\alpha$ disruption in the MPOA decreased only sexual behavior and in the MeA failed to alter either behavior (Sano et al., 2013). On the other hand, when $\mathrm{ER} \alpha$ was prepubertally knocked down in the MeA at postnatal day (P) 21 (which permanently suppressed ER $\alpha$ expression thereafter), both sexual and aggressive behaviors tested in adulthood were greatly reduced (Sano et al., 2015). These findings suggest that $\mathrm{ER} \alpha$ in each site is differently involved in the regulation of sexual and aggressive behaviors, through either organizational action during pubertal period (Schulz et al., 2004; Sisk and Foster, 2004; Sisk, 2015) or activational action at the time of testing in adult.

In contrast to $\mathrm{ER} \alpha$, the brain site-specific role of $\mathrm{ER} \beta$ for both organizational and activational action by gonadal steroids still remains unclear. Studies using an ER $\beta$ specific agonist diarylpropionitrile (DPN) revealed that neonatal $E R \beta$ activation may play a role in the expression of male social behavior in adulthood (Patisaul and Bateman, 2008), but a role of ER $\beta$ during pubertal period has not been identified. Furthermore, in adulthood, it is reported that DPN treatment into the MeA facilitates male sexual behavior in gonadectomized rats only in males simultaneously treated with an $\mathrm{ER} \alpha$ agonist (Russell et al., 2012). Considering that $\mathrm{ER} \beta$ may be involved primarily in modulatory regulation of behavior, it is necessary to further investigate the effects of brain-site-specific manipulation of $E R \beta$ in animals that are otherwise maintained as intact. Among a number of brain sites expressing high levels of $\mathrm{ER} \beta$, we have focused on the MPOA and MeA to determine the effects of prepubertal and postpubertal knockdown. These two areas have been implicated in the regulation of male social behaviors including not only sexual and aggressive behavior (Hull et al., 1999; Paredes, 2003; Veening et al., 2005) but also male-type sexual preference (Kondo and Sachs, 2002; Dhungel et al., 2011) and social information processing (Baum, 2009).

In the present study, we examined the effects of prepubertal application of AAV-mediated ER $\beta$ silencing, which site-specifically disrupts the expression of ER $\beta$ $(\beta E R K D)$ both during pubertal period and at the time of testing in adult (Experiment 1). Given positive knockdown effects on behaviors, we then tested whether similar behavioral alteration could be induced in mice with postpubertal $\beta E R K D$ in the MPOA (Experiment 2). In the MeA where prepubertal $\beta$ ERKD had no effects on sexual and aggressive behaviors, we performed more thorough analysis of male-type sexual preference (Experiment 3).

\section{Materials and Methods}

\section{Experimental animals}

Gonadally intact ICR/Jcl male mice were used as experimental animals. They were originally purchased from a commercial breeder (CLEA Japan) and maintained in a breeding colony at the University of Tsukuba. All mice were kept under standard housing conditions $\left(23 \pm 2^{\circ} \mathrm{C}\right.$, $12 \mathrm{~h}$ light/dark cycle with lights off at 12:00 P.M.) in polypropylene clear plastic cages $(19 \times 29 \times 12 \mathrm{~cm}$; Allentown) with corncob bedding. Food and water were provided ad libitum. All procedures were conducted in 
accordance with the National Institutes of Health guidelines and were approved by the Animal Care and Use Committee and the Recombinant DNA Use Committee at University of Tsukuba. All efforts were made to minimize the number of animals and their suffering.

\section{Estrogen receptor $\beta$ silencing using small hairpin RNA}

Experimental animals were stereotaxically injected with AAV vectors expressing a small hairpin RNA (shRNA), either prepubertally on P21 (Experiment 1) or postpubertally in adulthood (Experiments 2 and 3). AAV-shRNA against either the sequence specific for the ER $\beta$ gene (AAV-shER $\beta$ : 5'GATCCCCGCCACGAATCAGTGTACCATCTTCCTGTCA ATGGTACACTGATTCGTGGCTTITTGGAAT-3' and 5' CTAGAGCCACGAATCAGTGTACCATTGACAGGAAGATGGTACACTGATTCGTGGCGGG-3') or the sequence specific for luciferase (LUC) as control (AAV-shLUC: 5' GATCCCCCCGCTGGAGAGCAACTGCATCTTCCTGTCA ATGCAGTTGCTCTCCAGCGGTTTTTGGAA-3' and 5' CTAGTTCCAAAAACCGCTGGA GAGCAACTGCATGAGCAACTGCATTGACAGGAAGATGCAGTTGCTCTCCAGCGGGGG-3') were used. The nucleotides specific for ER $\beta$ and LUC are underlined. These vectors also expressed enhanced green fluorescent protein (GFP) as a reporter to visually detect transfected neurons.

Mice were anesthetized with sodium pentobarbital (60 $\mathrm{mg} / \mathrm{kg}$ ) and placed in a stereotaxic frame (David Kopf Instruments). A 26 G injection needle attached to a $10 \mu \mathrm{l}$ Hamilton syringe was inserted by aiming for either the MeA or MPOA (coordinates were determined for each experiment separately). Each animal was bilaterally injected with $1 \mu \mathrm{l}$ of either AAV-shER $\beta$ or AAV-shLUC $\left(10^{12}\right.$ packaged genomic particles, $0.5 \mu \mathrm{l} /$ hemisphere) over 5 min. The needle was left in place for an additional $10 \mathrm{~min}$ following the end of the infusion.

\section{Behavioral tests}

Sexual behavior test

Each experimental animal was tested for sexual behavior against a receptive female mouse in its home cage. Each trial was $30 \mathrm{~min}$ and conducted under red light illumination during the dark phase of the light/dark cycle. At the beginning of each trial, a hormonally primed ovariectomized (OVX) ICR/Jcl female mouse was introduced. To ensure high sexual receptivity, all females were subcutaneously injected with $10 \mu \mathrm{g}$ estradiol benzoate in 0.1 $\mathrm{ml}$ sesame oil at 48 and $24 \mathrm{~h}$, and $500 \mu \mathrm{g}$ progesterone in $0.1 \mathrm{ml}$ sesame oil at 4-6 h before testing. Each male was tested against a different female mouse in each of the repeated trials. The number of mounts and intromissions, and the latency to the first mount or intromission were recorded.

\section{Aggressive behavior test}

Aggressive behavior was assessed in a residentintruder paradigm for 15 min under red light illumination during the dark phase of the light/dark cycle. At the beginning of the test, an age-matched gonadally intact $\mathrm{ICR} / \mathrm{Jcl}$ male mouse (intruder) was introduced into a home cage of an experimental animal (resident). All intruder mice were olfactory bulbectomized (OBX) and grouphoused (3-5 animals/cage). OBX was conducted to inhibit offensive aggression by intruders. Each resident mouse was tested against a different intruder mouse in each of the repeated aggression tests. An aggressive bout was defined as a series of behavioral interactions consisting of at least one of the following: chasing, boxing, tail rattling, wrestling, biting, and offensive lateral attack (often accompanied by biting). The number and cumulative duration of aggressive bouts were recorded. A maximum of 3 $\mathrm{s}$ could elapse between two aggressive bouts were considered as one aggressive bout. If the interval exceeded 3 $\mathrm{s}$, the two bouts were scored as two separate aggressive bouts.

\section{Sexual preference test}

Each experimental mouse was tested for sexual preferences of a receptive female over a nonreceptive female (PTFF) and a receptive female over an intact male (PTFM). Each test was $15 \mathrm{~min}$ and conducted under white light illumination (26 lux) during dark phase of the light/dark cycle. The testing apparatus consisted of a white plastic testing cage $(31 \times 35 \times 17)$ placed centrally in a white polyvinyl chloride box $(46 \times 51 \times 25 \mathrm{~cm})$. The test cage was covered with a clear acrylic board during tests and a video camera was placed $57 \mathrm{~cm}$ from the bottom of the testing cage. Clear sectoral Plexiglas cylinders $(7 \mathrm{~cm}$ in radius, 16 $\mathrm{cm}$ in height) with 13 holes (6 $\mathrm{mm}$ diameter) near the bottom $3 \mathrm{~cm}$ of the cylinder (Mouse Cylinder SIOT3, O'Hara) were used to present opponent mice. Experimental mice were able to sniff olfactory cues from stimulus mice through perforated parts of the cylinders.

At least $2 \mathrm{~d}$ before testing, each experimental mouse was transferred to a testing cage with clean bedding and allowed to establish its own home territory. On the day of testing, they were first habituated to two empty cylinders for $1 \mathrm{~h}$. The cylinders were placed at diagonal corners of the testing cage. At the beginning of the test, empty cylinders were removed and two cylinders with stimulus animals were placed at the same two diagonal corners. In PTFF, a hormonally primed (for detailed conditions, see Sexual behavior test) OVX C57BL/6J female mouse [receptive female (RF)] and an OVX C57BL/6J female mouse without hormonal priming [nonreceptive female (XF)] were used as stimuli. In PTFM, a RF and a gonadally intact C57BL/6J male (IM) mouse were used. After completion of each test, cylinders were thoroughly washed, wiped with $70 \%$ ethanol, and then air-dried.

Social investigation (SI) was defined as sniffing toward each stimulus animal through the holes of the cylinder. The cumulative duration of SI to each stimulus mouse was recorded separately. A maximum of $1 \mathrm{~s}$ could elapse between two Sls to be considered as one bout. If the interval exceeded $1 \mathrm{~s}$, they were recorded as two bouts.

\section{Quantitative analysis of behavioral data}

All behavioral tests were recorded using digital video cameras. All video recordings were scored by an experimenter unaware of the animals' experimental group, using a digital event recorder program (Recordia 1.0b, O'Hara). 
Behavioral data from sexual and aggressive behavior tests was analyzed by a two-way ANOVA with repeated measurements for main effects of vector treatment, tests, and their interactions. The data from sexual preference tests was analyzed in each vector treatment group separately by a paired $t$ test between two stimulus mice. All data were analyzed using the SPSS v21.0 (SPSS). Statistically significant differences were considered at $p<0.05$. Superscript letters listed with $p$-values correspond to the statistical tests shown in Table 1.

\section{Histological analysis}

Preparation of brain tissues for immunohistochemistry

After completion of the last behavioral tests, all experimental animals were deeply anesthetized with heparin-containing pentobarbital sodium solution (60 $\mathrm{mg} / \mathrm{kg}$ body weight, i.p.). They were then perfused through the left cardiac ventricle with $40 \mathrm{ml}$ of $100 \mathrm{~mm}$ phosphate buffered saline (PBS), pH 7.2, for blood removal, followed by $40 \mathrm{ml}$ of $4 \%$ paraformaldehydecontaining $100 \mathrm{~mm}$ phosphate buffer (PB), pH 7.2, for fixation with the use of a peristaltic pump. Brains were removed and postfixed in the same fixative at $4^{\circ} \mathrm{C}$ for $24 \mathrm{~h}$. After cryoprotection in $30 \%$ sucrose in $100 \mathrm{~mm}$ PB at $4^{\circ} \mathrm{C}$, coronal sections (30 $\mu \mathrm{m}$ thickness) were prepared using a freezing microtome. Serial sections were collected in sets of four at $120 \mu \mathrm{m}$ intervals, and stored in anti-freezing buffer (30\% ethylene glycol and 30\% glycerol in $0.05 \mathrm{M}$ Tris-buffered saline (TBS), $\mathrm{pH} 7.2$, at $-20^{\circ} \mathrm{C}$ until use.

\section{Immunohistochemistry}

Freely floating sections were incubated in PBS containing $0.2 \%$ triton $\mathrm{X}(\mathrm{PBS}-\mathrm{X})$ with $0.3 \% \mathrm{H}_{2} \mathrm{O}_{2}$ for $20 \mathrm{~min}$ at room temperature (RT) for blocking. After washing, sections were pretreated with $5 \%$ bovine serum albumin in PBS-X (blocking buffer) for $2 \mathrm{~h}$ at RT. The sections were then incubated with goat polyclonal anti-GFP antiserum (1:5000; ab6673, Abcam) in blocking buffer for 1 night at $4^{\circ} \mathrm{C}$. They were washed and incubated with biotinylated rabbit anti-goat secondary antiserum (1:250; Vector Laboratories) in blocking buffer for $2 \mathrm{~h}$ at RT. After washing, sections were reacted to avidin-biotin complex (Vectastain ABC Elite kit, Vector Laboratories) PBS for $1 \mathrm{~h}$ at RT, and washed. They were then incubated in $0.02 \%$ diaminobenzidine (DAB) and $0.003 \% \mathrm{H}_{2} \mathrm{O}_{2}$ in PBS for $2 \mathrm{~min}$, followed by wash with PBS. A few sections from each group were also processed for double-immunohistochemical staining for GFP and ER $\beta$. Prior to immunohistochemistry for GFP, they were incubated with rabbit polyclonal ER $\beta$ antiserum (1: 1000; Z8P, lot 10766190, Zymed Laboratories) for $3 \mathrm{~d}$ at $4^{\circ} \mathrm{C}$ followed by biotinylated goat anti-rabbit secondary antiserum (1:250; Vector Laboratories) for $2 \mathrm{~h}$ and visualized in $0.03 \% \mathrm{DAB}, 0.15 \% \mathrm{NiNH}_{4} \mathrm{SO}_{4}$, and $0.003 \% \mathrm{H}_{2} \mathrm{O}_{2}$ in TBS for $12-14 \mathrm{~min}$, followed by wash with TBS, $\mathrm{pH}$ 7.2.

All sections were mounted on gelatin-coated slides, air-dried, dehydrated through ascending series of ethanol, cleaned with xylene, and coverslipped with Permount (Fisher Scientific).
Analysis of immunopositive cells

Nine sections containing the MPOA (bregma 0.38 to -0.58 ) and nine sections containing the MeA (bregma -1.10 to -2.06 ) were selected for histological analysis of immunopositive cells for GFP. Each brain area was photographed with a digital camera mounted to a microscope (BZ-X710, KEYENCE). Spread of GFP-immunopositive cells was recorded for confirmation of AAV infection in the targeted area. We also selected three double-immunostained sections in the MPOA (bregma 0.02, -0.10 , and -0.22 ) and in the MeA (bregma -1.82, -1.94, and -2.06) where most intensive ER $\beta$ expression were observed in the control groups. In these sections, we counted ( 3 mice per group) number of ER $\beta$-immunopositive cells and double-labeled cells for ER $\beta$ and GFP in each side of the hemisphere within the targeted site. The data was analyzed in each section separately by a Welch's $t$ test between two vector treatment groups using the SPSS v21.0 (SPSS). Statistically significant differences were considered at $p<0.05$. Superscript letters listed with $p$-values correspond to the statistical tests shown in Table 1.

\section{Experimental Design}

Experiment 1 : prepubertal treatment in the MPOA and $\mathrm{MeA}$

A total of 12 litters of ICR/Jcl male mice were assigned to either MPOA or MeA groups on P21 after being weaned (Fig. 1, top). Mice from each litter were further subdivided into two shRNA injection groups of either AAV-shER $\beta$ or AAV-shLUC. Those four groups were designated as prepubertal treatment MPOA$\beta$ ERKD $(n=11), \quad$ MPOA-Cont $(n=13), \quad$ MeA- $\beta$ ERKD $(n=9)$, and MeA-Cont $(n=9)$. Coordinates for the MPOA group were AP +0.02, $M L \pm 0.5, D V-5.2$, and those for the MeA group were AP $-1.25, \mathrm{ML} \pm 2.2$, DV -5.15 . All coordinates were determined based on The Mouse Brain Stereotaxic Coordinates (Paxinos and Franklin, 2001) with an adjustment for the brain size on P21. All mice were then group housed with their littermates (4-5 mice per cage) until they were tested for sexual and aggressive behavior in adulthood as gonadally intact $(11.9 \pm 0.21$ weeks of age at the first behavioral test). One week before the first behavioral test, all mice were individually housed. Three sexual behavior tests and three sets of aggressive behavior tests (each set consisting of aggression tests in 3 consecutive days) were done biweekly in alternate weeks for a total of 6 weeks. After the completion of the last behavioral test, brain tissues were collected and processed for immunohistochemistry for GFP and ER $\beta$.

\section{Experiment 2: postpubertal treatment in the MPOA} Gonadally intact adult male mice (12.2 \pm 1.00 weeks of age at injection) were stereotaxically injected with either AAV-shER $\beta$ (MPOA- $\beta$ ERKD, $n=11$ ) or AAV-shLUC (MPOA-Cont, $n=14$; Fig. 1, middle). Coordinates were AP $+0.02, \mathrm{ML} \pm 0.5$, DV -5.65 . One week after surgery, all mice were individually housed and a series of biweekly sexual and aggressive behavior tests (described in Experiment 1) was started on the following week. After the 


\section{Experiment 1}

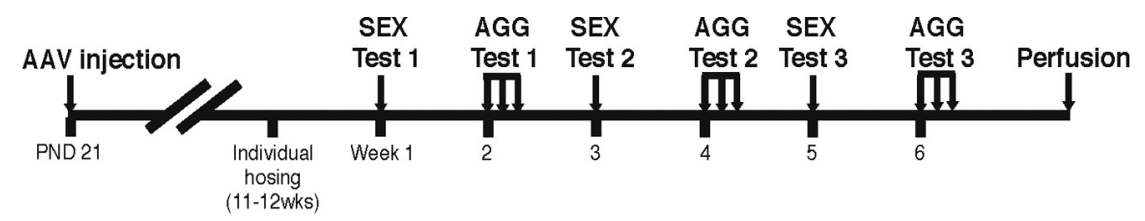

Experiment 2

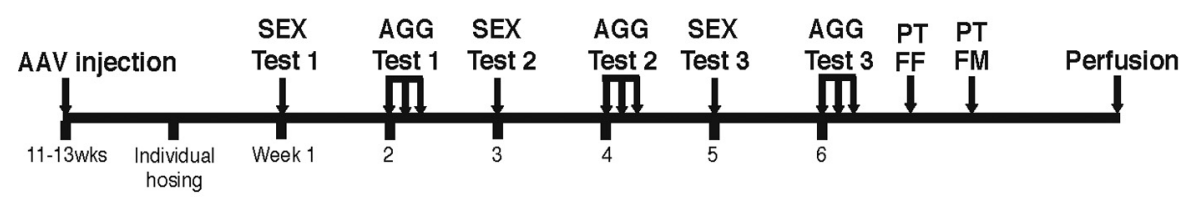

Experiment 3

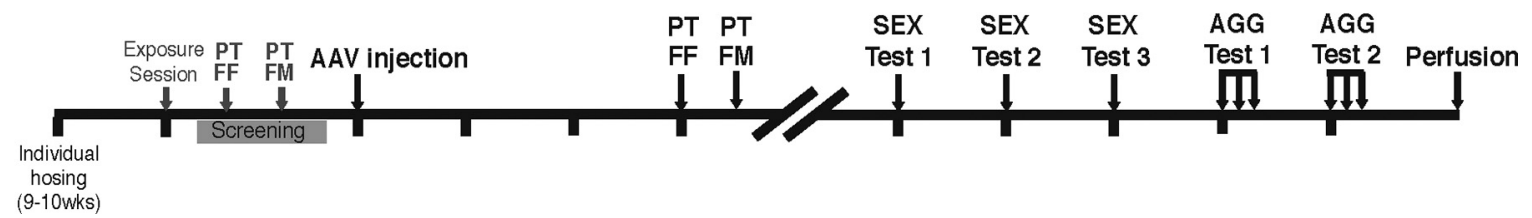

Figure 1. Experimental procedures of Experiment 1 (top), Experiment 2 (middle), and Experiment 3 (bottom). Ticks under the horizontal bar indicate 1 week. SEX, Sexual behavior; AGG, aggressive behavior.

completion of behavioral tests, brain tissues were collected and processed for immunohistochemistry for GFP.

\section{Experiment 3: postpubertal treatment in the MeA}

Gonadally intact adult male mice were individually housed $(9.7 \pm 0.49$ weeks of age; Fig. 1 , bottom). Starting 1 week later, they were given an exposure session. Briefly, a hormonally primed receptive C57BL/6J female mouse was placed in a clear columnar Plexiglas cylinder $(7 \mathrm{~cm}$ in diameter, $16 \mathrm{~cm}$ in height with 28 holes of $6 \mathrm{~mm}$ diameter near the bottom $3 \mathrm{~cm}$ of the cylinder; Mouse Cylinder SIOT1, O'Hara) and presented in the center of the male's home cage for $30 \mathrm{~min}$. Starting at least $4 \mathrm{~d}$ after the exposure session, experimental animals were transferred to white plastic testing cages and given two screening sexual preference tests, one with PTFF and the other with PTFM paradigms. Only the mice that showed longer SI toward a receptive female over nonreceptive female (PTFF paradigm) and intact male (PTFM paradigm) were selected. They were then injected with either AAV-shER $\beta$ (MeA- $\beta$ ERKD, $n=15$ ), or AAV-shLUC (MeA-Cont, $n=13$ ) on 15-16 d after the completion of the screening tests. Coordinates: AP $-1.7, \mathrm{ML} \pm 2.4$, DV -5.4 . Three weeks after injections, all mice were given PTFF and PTFM sexual preference tests at $4 \mathrm{~d}$ intervals. Starting 1 week after the completion of sexual preference tests, they were given three weekly sexual behavior tests followed by two sets of aggressive behavior tests (each set consisting of aggression tests in 3 consecutive days) during 5 weeks. After the completion of the last behavioral test, brain tissues were collected and processed for immunohistochemistry for GFP.

\section{Results}

\section{Experiment 1: prepubertal treatment in the MPOA and $\mathrm{MeA}$}

Effects of prepubertal silencing of ER $\beta$ in the MPOA on sexual and aggressive behavior

Prepubertal $\beta$ ERKD in the MPOA did not affect the expression of sexual behavior tested in adulthood (Fig. 2A).
There were no significant main effects of treatment and test, and interaction of treatment and test in the number of mounts $^{a}$ and intromissions ${ }^{b}$, or latency to the first mount ${ }^{c}$.

On the other hand, the levels of aggressive behavior were significantly reduced by prepubertal ER $\beta$ knockdown in the MPOA (Fig. $2 B$ ). Mice in the MPOA- $\beta$ ERKD group showed significantly fewer number $\left(F_{(1,22)}=4.631\right.$; $\left.p=0.043^{\mathrm{d}}\right)$ and shorter duration $\left(F_{(1,22)}=5.078 ; p=\right.$ $0.035^{\mathrm{e}}$ ) of aggressive bouts compared with those in the MPOA-Cont group (main effects of test and interaction of treatment and test, n.s. ${ }^{\text {d,e }}$ ). We also examined whether any specific component(s) of aggressive behavior, particularly lateral attacks, which are the most vigorous type of aggressive behavior, might be altered by the treatment. However, we did not find any specific effects of prepubertal ER $\beta$ manipulation in the MPOA.

Examination of placement of the injection needle tip (Fig. 2C, top) and presence of GFP-immunopositive cells confirmed successful bilateral injections of AAV vectors within the MPOA for all mice used in behavioral analysis (Fig. 2C, bottom). In addition, ER $\beta$ expression was examined immunohistochemically. The number of $\mathrm{ER} \beta$-immunoreactive cells in the MPOA was significantly reduced in the MPOA- $\beta$ ERKD group compared with those in the MPOA-Cont group (bregma $+0.02, t_{(6.789)}=2.449$; $p=0.045^{f}$, bregma $-0.10, t_{(5.147)}=4.315 ; p=0.007^{9}$, bregma $-0.22, t_{(5.672)}=4.171 ; p=0.007^{\mathrm{h}}$, Fig. $2 D$, top; Table 2). Furthermore, coexpression of ER $\beta$ in GFPimmunopositive cells was detected by double-labeled immunohistochemistry in AAV-shLUC-injected control mice. On the other hand, ER $\beta$ expression was absent in the GFP-immunopositive cells of an AAV-shER $\beta$-injected mice, although we found $E R \beta$ expression in a few GFPnegative cells in these mice (Fig. 2D, bottom; Table 2). These anatomical analysis confirmed successful knockdown of ER $\beta$ expression in transfected cells in the MPOA$\beta$ ERKD group. 
Table 1. Statistical table

\begin{tabular}{|c|c|c|c|c|}
\hline & Data structure & Test & Exact $p$ value & $N$ \\
\hline \multicolumn{5}{|l|}{ E1-MPOA } \\
\hline a Mount $n$ & Two-factor, mixed design: bw (trt) and wi (test) & ANOVA & $\begin{array}{l}0.305 \text { (trt) } \\
0.086 \text { (test) } \\
0.185 \text { (trt } \times \text { test) }\end{array}$ & $10 \mathrm{KD} ; 10$ Cont \\
\hline b Intromission $n$ & Two-factor, mixed design: bw(trt) and wi (test) & ANOVA & $\begin{array}{l}0.537 \text { (trt) } \\
0.971 \text { (test) } \\
0.741 \text { (trt } \times \text { test) }\end{array}$ & $10 \mathrm{KD} ; 10$ Cont \\
\hline c Mount latency & Two-factor, mixed design: bw(trt) and wi (test) & ANOVA & $\begin{array}{l}0.366 \text { (trt) } \\
0.925 \text { (test) } \\
0.130 \text { (trt } \times \text { test) }\end{array}$ & $10 \mathrm{KD} ; 10$ Cont \\
\hline d Agg $n$ & Two-factor, mixed design: bw(trt) and wi (test) & ANOVA & $\begin{array}{l}0.043 \text { (trt) } \\
0.123 \text { (test) } \\
0.434 \text { (trt } \times \text { test) }\end{array}$ & $11 \mathrm{KD} ; 13$ Cont \\
\hline e Agg duration & Two-factor, mixed design: bw(trt) and wi (test) & ANOVA & $\begin{array}{l}0.035 \text { (trt) } \\
0.544 \text { (test) } \\
0.203 \text { (trt } \times \text { test) }\end{array}$ & $11 \mathrm{KD} ; 13$ Cont \\
\hline f cell $n$ & One-factor, bw (trt) & Welch's $t$ test & 0.045 & $6^{+} \mathrm{KD} ; 6^{+}$Cont \\
\hline g cell $n$ & One-factor, bw (trt) & Welch's $t$ test & 0.007 & $6^{+} \mathrm{KD} ; 6^{+}$Cont \\
\hline h cell $n$ & One-factor, bw (trt) & Welch's $t$ test & 0.007 & $\begin{array}{l}6^{+} \mathrm{KD} ; 6^{+} \\
\text {Cont }\end{array}$ \\
\hline \multicolumn{5}{|l|}{ E1-MeA } \\
\hline i Mount $n$ & Two-factor, mixed design: bw(trt) and wi (test) & ANOVA & $\begin{array}{l}0.677 \text { (trt) } \\
0.102 \text { (test) } \\
0.919 \text { (trt } \times \text { test) }\end{array}$ & $8 \mathrm{KD}$; 9 Cont \\
\hline j Intromission $n$ & Two-factor, mixed design: bw(trt) and wi (test) & ANOVA & $\begin{array}{l}0.285 \text { (trt) } \\
0.171 \text { (test) } \\
0.069 \text { (trt } \times \text { test) }\end{array}$ & $8 \mathrm{KD} ; 9$ Cont \\
\hline k Mount latency & Two-factor, mixed design: bw(trt) and wi (test) & ANOVA & $\begin{array}{l}0.972 \text { (trt) } \\
0.383 \text { (test) } \\
0.600 \text { (trt } \times \text { test) }\end{array}$ & 8 KD; 9 Cont \\
\hline I Agg $n$ & Two-factor, mixed design: bw(trt) and wi (test) & ANOVA & $\begin{array}{l}0.823 \text { (trt) } \\
0.246 \text { (test) } \\
0.947 \text { (trt } \times \text { test) }\end{array}$ & 9 KD; 9 Cont \\
\hline m Agg duration & Two-factor, mixed design: bw(trt) and wi (test) & ANOVA & $\begin{array}{l}0.636 \text { (trt) } \\
0.815 \text { (test) } \\
0.570 \text { (trt } \times \text { test) }\end{array}$ & 9 KD; 9 Cont \\
\hline $\mathrm{n}$ cell $n$ & One-factor, bw (trt) & Welch's $t$ test & 0.0001 & $6^{+} \mathrm{KD} ; 6^{+}$Cont \\
\hline o cell $n$ & One-factor, bw (trt) & Welch's $t$ test & 0.00001 & $6^{+} \mathrm{KD} ; 6^{+}$Cont \\
\hline $\begin{array}{l}\mathrm{p} \text { cell } n \\
\text { E2 }\end{array}$ & One-factor, bw (trt) & Welch's $t$ test & 0.0009 & $6^{+} \mathrm{KD} ; 6^{+}$Cont \\
\hline q Mount $N$ & Two-factor, mixed design: bw(trt) and wi (test) & ANOVA & $\begin{array}{l}0.069 \text { (trt) } \\
0.014 \text { (test) } \\
0.202 \text { (trt } \times \text { test) }\end{array}$ & $11 \mathrm{KD} ; 14$ Cont \\
\hline$r$ Intromission $n$ & Two-factor, mixed design: bw(trt) and wi (test) & ANOVA & $\begin{array}{l}0.123 \text { (trt) } \\
0.035 \text { (test) } \\
0.228 \text { (trt } \times \text { test) }\end{array}$ & $11 \mathrm{KD} ; 14$ Cont \\
\hline s Mount latency & Two-factor, mixed design: bw(trt) and wi (test) & ANOVA & $\begin{array}{l}0.077 \text { (trt) } \\
<0.001 \text { (test) } \\
0.153 \text { (trt } \times \text { test) }\end{array}$ & $11 \mathrm{KD} ; 14$ Cont \\
\hline t Agg $n$ & Two-factor, mixed design: bw(trt) and wi (test) & ANOVA & $\begin{array}{l}0.858 \text { (trt) } \\
0.021 \text { (test) } \\
0.828 \text { (trt } \times \text { test) }\end{array}$ & $11 \mathrm{KD} ; 14$ Cont \\
\hline u Agg duration & Two-factor, mixed design: bw(trt) and wi (test) & ANOVA & $\begin{array}{l}0.927 \text { (trt) } \\
0.036 \text { (test) } \\
0.796 \text { (trt } \times \text { test) }\end{array}$ & $11 \mathrm{KD} ; 14$ Cont \\
\hline \multicolumn{5}{|c|}{ 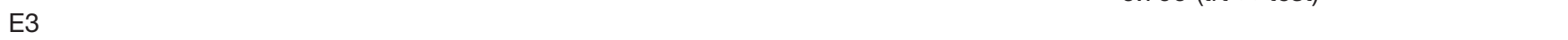 } \\
\hline v PTFF (Cont) & One-factor, wi (stim) & Paired $t$ test & 0.028 & 13 \\
\hline w PTFF (KD) & One-factor, wi (stim) & Paired $t$ test & 0.854 & 15 \\
\hline x PTFM (Cont) & One-factor, wi (stim) & Paired $t$ test & 0.001 & 13 \\
\hline y PTFM (KD) & One-factor, wi (stim) & Paired $t$ test & $<0.001$ & 15 \\
\hline z Mount $n$ & Two-factor, mixed design: bw(trt) and wi (test) & ANOVA & $\begin{array}{l}0.380 \text { (trt) } \\
0.001 \text { (test) } \\
0.359 \text { (trt } \times \text { test) }\end{array}$ & $14 \mathrm{KD} ; 12$ Cont \\
\hline
\end{tabular}




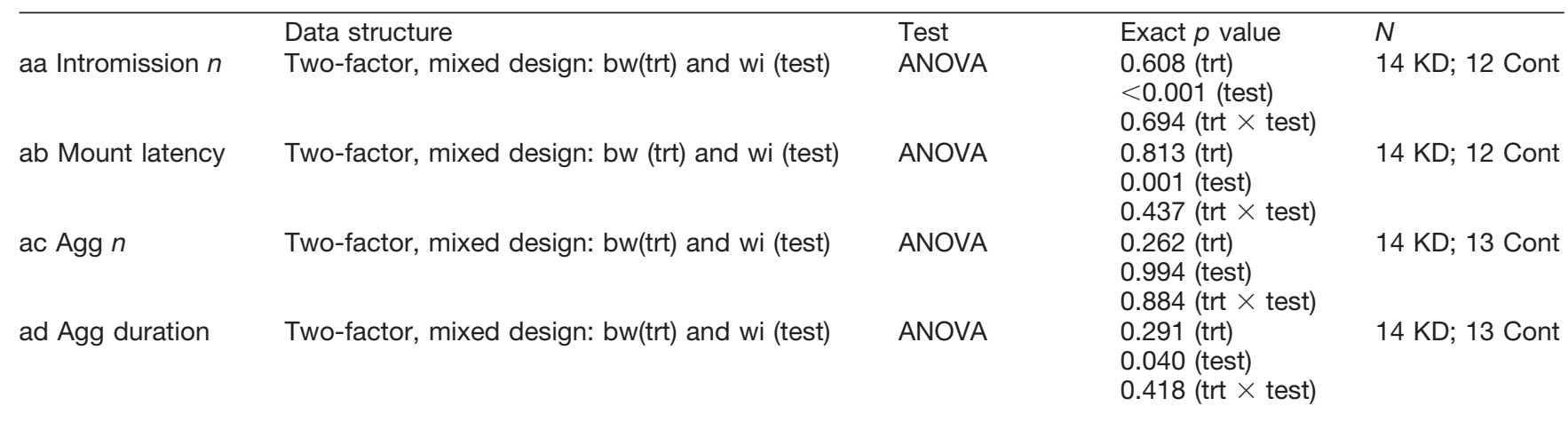

$n$, Number; agg, aggressive bout; cell $n$, total number of ER $\beta$-immunopositive cells; bw, between; wi, within; trt, vector treatment; KD, $\beta$ ERKD; Cont, Control; ,+ 2 hemispheres $\times 3$ mice.

\section{Effects of prepubertal silencing of $E R \beta$ in the MeA on} sexual and aggressive behaviors

Prepubertal silencing of $E R \beta$ in the MeA had no effects on the expression of either sexual or aggressive behaviors in adulthood. The number of mounts ${ }^{i}$ and intromissions ${ }^{j}$, and latency to the first mount ${ }^{k}$ in the MeA- $\beta$ ERKD group were not different from those in the MeA-Cont group (Fig. 3A). Likewise, both number and duration ${ }^{\mathrm{m}}$ of aggressive bouts were not different between the two treatment groups (Fig. 3B).

Examination of placement of the injection needle tip (Fig. 3C, top) and presence of GFP-immunopositive cells confirmed successful bilateral injections of AAV vectors within the MeA for all mice used in behavioral analysis (Fig. 3C, bottom). In addition, the number of $\mathrm{ER} \beta$ immunoreactive cells in the MeA was greatly reduced in the MeA- $\beta$ ERKD group compared with those in the MeACont group (bregma -1.82, $t_{(5.739)}=9.443 ; p<0.0001^{\mathrm{n}}$, bregma $-1.94, t_{(7.485)}=5.267 ; p<0.0001^{\circ}$, bregma $-2.06, t_{(8.407)}=9.314 ; p=0.0009^{p}$, Fig. 3D, top; Table 2). Furthermore, double-labeled immunohistochemistry revealed that coexpression of ER $\beta$ and GFP was frequently observed in the AAV-shLUC-injected mice but not in the AAV-shER $\beta$-injected mice (Fig. 3D, bottom; Table 2). These anatomical analysis confirmed successful knockdown of ER $\beta$ expression in transfected cells in the MeA$\beta E R K D$ group.

\section{Experiment 2: postpubertal treatment in the MPOA}

There was no difference in male sexual behaviors between adult MPOA- $\beta$ ERKD and MPOA-Cont groups (Fig. $4 A$ ), as predicted from the results of prepubertal $\beta E R K D$ in which ER $\beta$ expression was presumably suppressed throughout the life after AAV-shER $\beta$ injection (Experiment $1)$. There was no overall significant main effect of treatment nor interaction between treatment and test in the number of mounts ${ }^{q}$ and intromissions ${ }^{r}$ and the latency to the first mount ${ }^{\mathrm{s}}$, although overall significant main effect of test (number of mounts: $F_{(1.712,39.373)}=5.078, p=0.014^{q}$; number of intromissions: $F_{(1.448,33.296)}=4.185, p=0.035^{r}$; both adjusted by Greenhouse-Geisser; latency to the first mount: $\left.F_{(2,46)}=9.470, p<0.001^{\mathrm{s}}\right)$.

On the other hand, effects of AAV-shER $\beta$ injection in adulthood on aggressive behavior greatly contrasted with those induced by prepubertal injection. Unlike suppres- sive effects on the number and duration of aggressive bouts by prepubertal $\beta$ ERKD found in Experiment 1, mice from MPOA- $\beta$ ERKD and MPOA-Cont groups showed equivalent levels of aggressive behaviors (Fig. 4B). There were no significant main effects of treatment and interaction of treatment and test on either measurement, ${ }^{\mathrm{t}, \mathrm{u}}$ although there were overall significant increases in the number $\left(F_{(2,46)}=4.199, p=0.021^{t}\right)$ and duration $\left(F_{(2,46)}=\right.$ $\left.3.582, p=0.036^{\mathrm{u}}\right)$ of aggressive bouts along repeated tests.

Examination of placement of the injection needle tip and presence of GFP-immunopositive cells confirmed successful bilateral injections of AAV vectors within the MPOA for all mice used in behavioral analysis (data not shown).

\section{Experiment 3: postpubertal treatment in the MeA}

For thorough analysis of sexual preference (which has been reported to be influenced by social experience), we performed two types of tests prior to sexual and aggressive tests in this experiment. We found that lack of $\mathrm{ER} \beta$ in the MeA interferes with sexual preference toward a RF over a XF, tested in the PTFF paradigm but not over a IM, tested in the PTFM paradigm (Fig. 5A). In PTFF tests (Fig. $5 A$, left), MeA-Cont males investigated RFs significantly longer than XFs $\left(t_{(12)}=2.504, p=0.028^{\mathrm{V}}\right)$, whereas MeA- $\beta$ ERKD males failed to show such preference $\left(t_{(14)}=\right.$ $0.199, p=0.854$, n.s. $\left.{ }^{w}\right)$. On the other hand, in PTFM tests (Fig. $5 A$, right), mice in both MeA- $\beta$ ERKD and MeA-Cont groups showed significantly longer SI duration toward RFs than toward IMs ( $\beta$ ERKD: $t_{(14)}=7.446, p<0.001^{\mathrm{y}}$; Cont: $t_{(12)}=4.534, p=0.001^{\mathrm{x}}$ ).

$\mathrm{ER} \beta$ silencing only in adulthood by postpubertal injection of AAV-shER $\beta$ had no significant effects on the expression of either sexual and aggressive behaviors, as predicted from the findings in prepubertal treatment in the MeA (Experiment 1). There were no overall significant differences between MeA- $\beta$ ERKD and MeA-Cont groups in the number of mounts ${ }^{z}$ and intromissions ${ }^{\text {aa }}$ or latency to the first mount ${ }^{a b}$ (Fig. 5B). In both groups, the levels of sexual behavior similarly increased with repetition of tests (number of mounts: $F_{(2,48)}=7.780, p=0.001^{z}$; number of intromissions: $\left.F_{(2,48)}=9.112, p<0.001^{\text {aa }}\right)$, with a decrease of latency to the first mount $\left(F_{(2,48)}=7.993 ; p=\right.$ $\left.0.001^{\mathrm{ab}}\right)$. In aggression tests, mice from MeA- $\beta$ ERKD and 
A
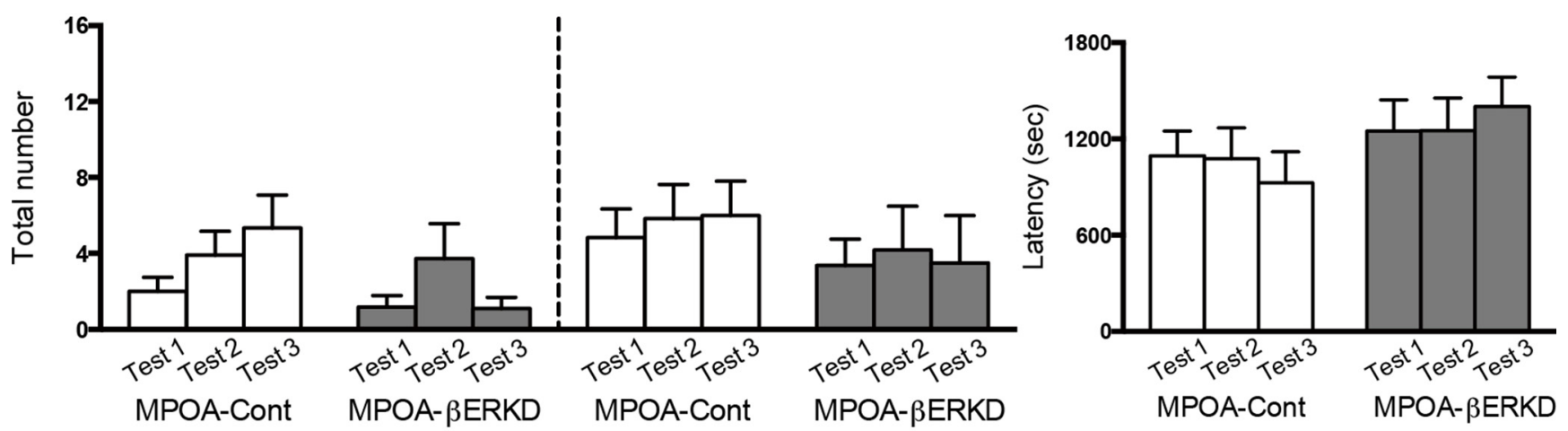

B

Number of Aggressive Bouts

\section{Duration of Aggressive Bouts}
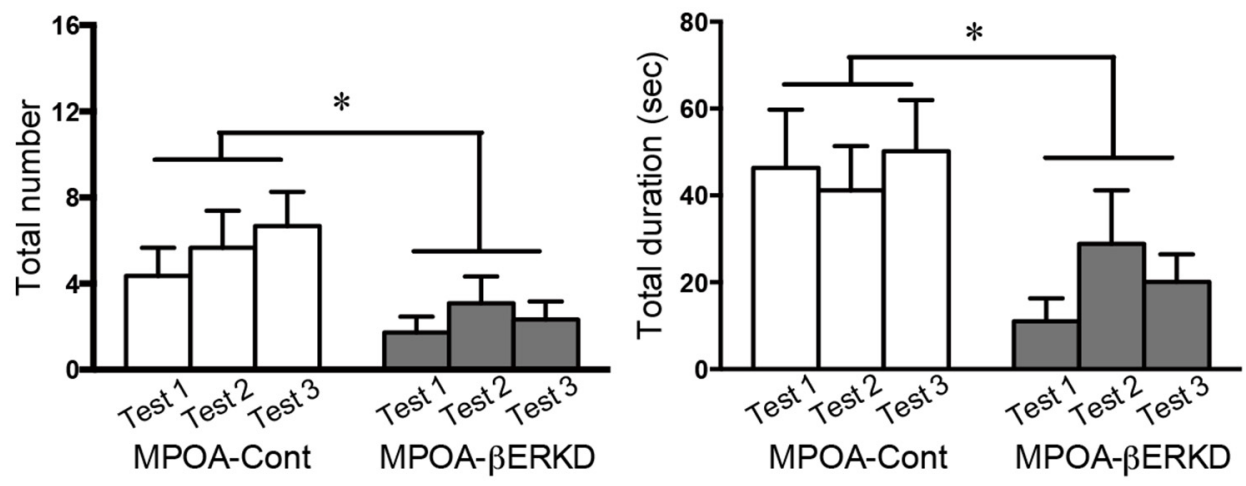

C

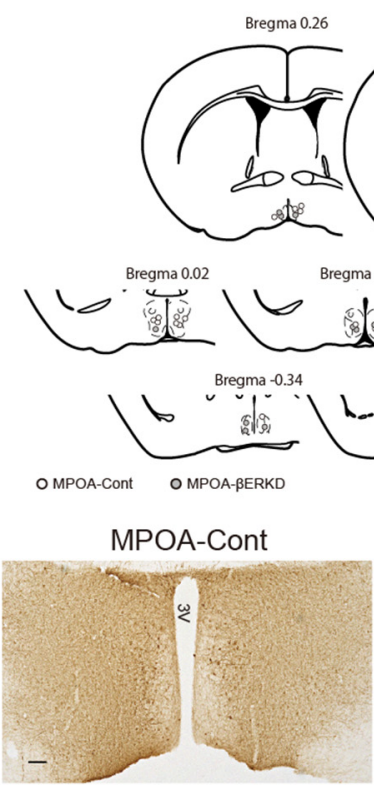

D
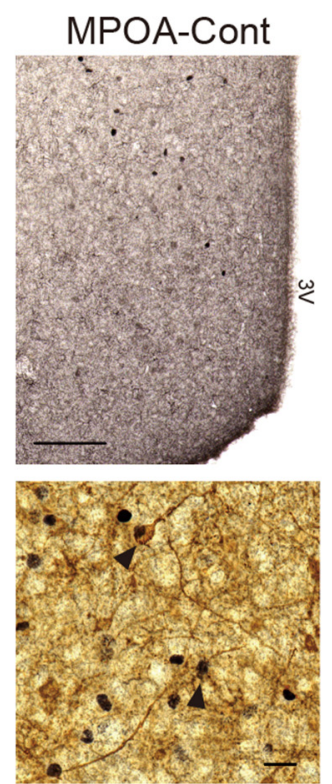

MPOA-ßERKD
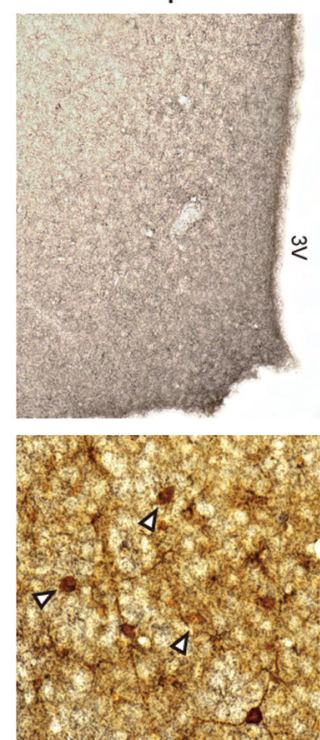

Figure 2. Effects of prepubertal silencing of ER $\beta$ in the MPOA on the expression of male sexual and aggressive behaviors in adulthood. $\boldsymbol{A}$, There was no difference between the MPOA-Cont and MPOA- $\beta$ ERKD groups in the number of mounts (left), intromissions (middle), or latency to the first mount (right). $\boldsymbol{B}$, The duration (left) and number (right) of aggressive bouts was significantly reduced in the MPOA- $\beta$ ERKD group compared with the MPOA-Cont group $(* p<0.05)$. All behavioral data in $\boldsymbol{A}$ and $\boldsymbol{B}$ are presented as mean + SEM. C , Histological diagrams depicting the placement of the injection needle tip for each mouse in the MPOA-Cont (open circles) and MPOA- $\beta$ ERKD (solid circles) groups (top), and representative photomicrographs of MPOA sections with single-immunohistochemical staining for GFP (bottom; at bregma -0.10). Scale bar, $100 \mu \mathrm{m}$. 3V, third ventricle. $\boldsymbol{D}$, Representative photomicrographs of MPOA sections with single-immunohistochemical staining for ER $\beta$ (top; at bregma -0.22 ), and MPOA 
continued

sections with double-immunostaining for GFP and ER $\beta$ (bottom). Number of ER $\beta$-immunoreactive cells in the targeted site was reduced in the $\beta$ ERKD group compared with the control group. Scale bars: top, $100 \mu \mathrm{m}$; bottom, $20 \mu \mathrm{m}$. Bottom, Black arrowheads indicate ER $\beta$ and GFP double-immunoreactive cells and white arrowheads indicate immunoreactive cells only for GFP.

MeA-Cont groups showed similar levels of aggressive behavior in terms of both number ${ }^{\text {ac }}$ and duration ${ }^{\text {ad }}$ of aggressive bouts (Fig. 5C). Examination of placement of the injection needle tip and presence of GFPimmunopositive cells confirmed successful bilateral injections of AAV vectors within the MeA for all mice used in behavioral analysis (data not shown).

\section{Discussion}

In the present study, we conducted site-specific knockdown of ER $\beta$ targeting the MPOA or MeA either on prepubertal $(21 \mathrm{~d}$ old $)$ or postpubertal (11 weeks old or later) age. We have found that ER $\beta$ in the MPOA during pubertal period may contribute to full expression of aggressive behavior in adulthood. In the MeA, we have found that $\mathrm{ER} \beta$ may be specifically involved in the control of sexual preference. To confirm successful silencing of ER $\beta$ expression in AAV transfected cells in the targeted brain site, we have performed double-immunohistochemical staining and found all the cells stained for GFP were ER $\beta$ negative in $\beta$ ERKD groups. It should be noted that the specificity of commercially available $\mathrm{ER} \beta$ antibodies except a few original lots of Zymed antibody Z8P has been controversial (Snyder et al., 2010). Therefore, we used an aliquot from one of earlier lots proven for its specificity previously (Shughrue and Merchenthaler, 2001; Nomura et al., 2003, 2005). Together, we could provide the first direct demonstration of site-specific role of $\operatorname{ER} \beta$ in the regulation of male-type social behavior.

\section{Role of ER $\beta$ in the MPOA in the regulation of sexual and aggressive behavior}

It has been known that the MPOA plays a role for the expression of male sexual behavior because copulation activates the MPOA neuronal activity (Coolen et al., 1997; Veening et al., 2005) and lesions of this area disrupt male sexual behavior (Hull et al., 2002). In the present study, any components of sexual behavior, ie, the number of mounts or intromissions, and the latency to the first mount, were affected by neither prepubertal nor postpu- bertal injection of AAV-shER $\beta$ to the MPOA. These results are contrasted with the findings reported in mice sitespecifically knocked down for ER $\alpha$ in the MPOA (Sano et al., 2013, 2015). In these studies, both prepubertal and postpubertal injection of AAV-shER $\alpha$ in the MPOA significantly decreased the number of attempted mounts, mounts, and intromissions. Therefore, even though both $\mathrm{ER} \alpha$ and $\mathrm{ER} \beta$ are expressed in the MPOA (Shughrue et al., 1997; Mitra et al., 2003), it is concluded that ER $\alpha$ may be primarily responsible for the facilitation of sexual behavior. Our results also indicate that for facilitation of sexual behavior via $\mathrm{ER} \alpha$, simultaneous $\mathrm{ER} \beta$ activation is not necessary. This is consistent with the finding reported in male rats treated with either $\mathrm{ER} \alpha$ or $\mathrm{ER} \beta$-specific agonist site-specifically in the MPOA (Russell et al., 2012).

We found that duration and number of bouts of aggressive behavior were greatly reduced by AAV-shER $\beta$ injection into the MPOA on $21 \mathrm{~d}$ of age (Experiment 1), which permanently suppressed ER $\beta$ expression throughout the life after the treatment in the target area. On the other hand, similar treatment in 11 to 12 weeks of age did not affect either measurements of aggressive behavior (Experiment 2). Therefore, decreased levels of aggression found in Experiment 1 was not due to a lack of ER $\beta$ expression at the time of testing in adult. Rather, our data is interpreted that ER $\beta$ expression in the MPOA may be necessary for organizational action of testosterone during development, particularly during pubertal period. It may be argued that behavioral alteration caused by prepubertal ER $\beta$ knockdown in the MPOA might be due to reduced levels of testosterone in $\beta$ ERKD mice. Although we did not measure circulating levels of testosterone in the present study, this seems unlikely because global $\beta$ ERKO male mice are known to have similar or increased levels of testosterone in adult or during pubertal period compared to wild-type mice (Couse and Korach, 1999; Nomura et al., 2002). Previous studies have implicated involvement of ER $\beta$ in neonatal masculinization (Patisaul and Bateman, 2008) or defeminization (Kudwa et al., 2005)

Table 2. Number of ER $\beta$-immunopositive cells

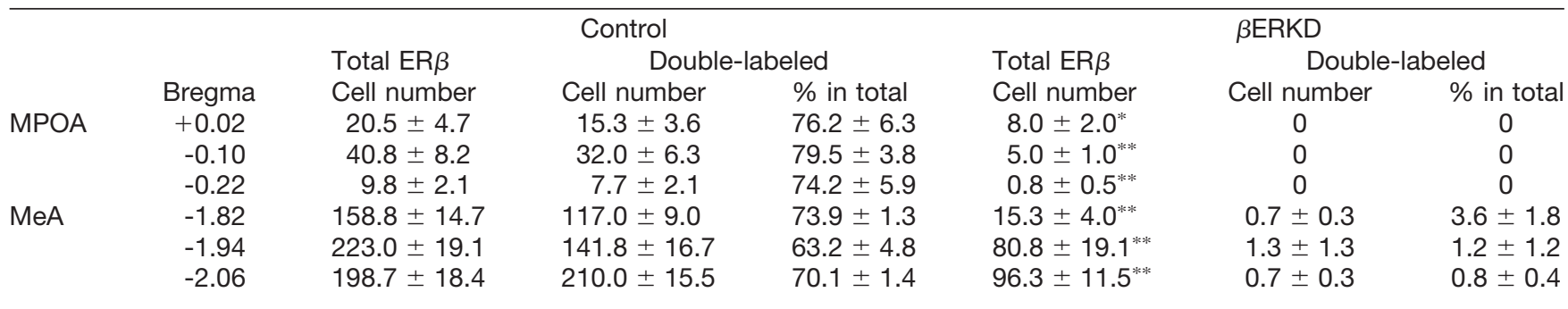

Total ER $\beta$ cell number, Number of ER $\beta$-immunopositive cells/side in the targeted area; double-labeled cell number, number of double-stained cells with ER $\beta$ and GFP; double-labeled \% in total, percentage of double-stained cells in the total number of ER $\beta$-immunopositive cells. $* p<0.05, * * p<0.01$ versus Control. 
A

Number of Mounts

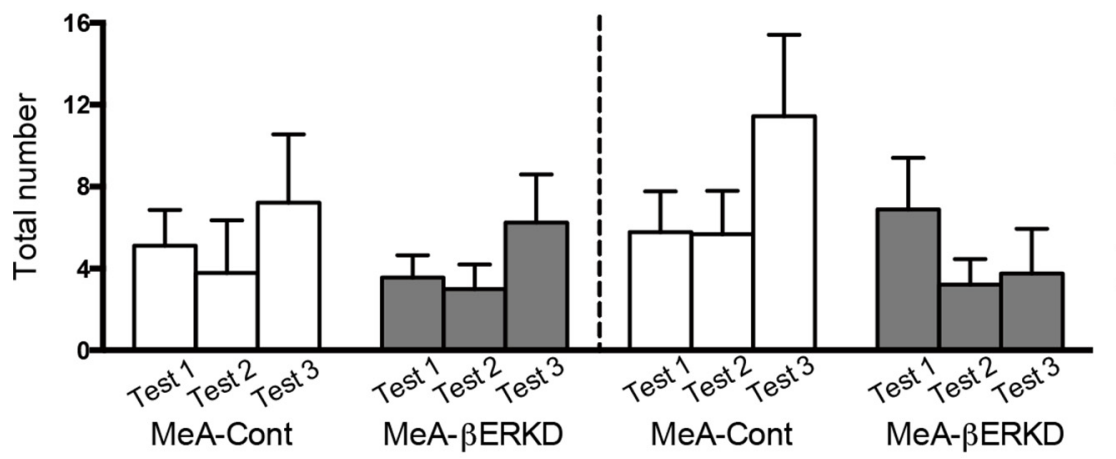

B

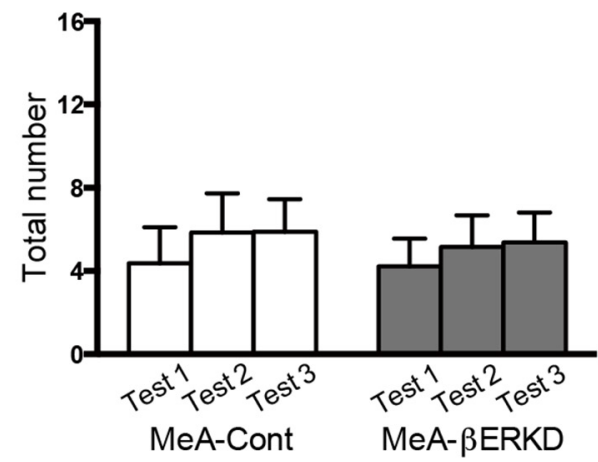

Number of Intromission
Duration of Aggressive Bouts

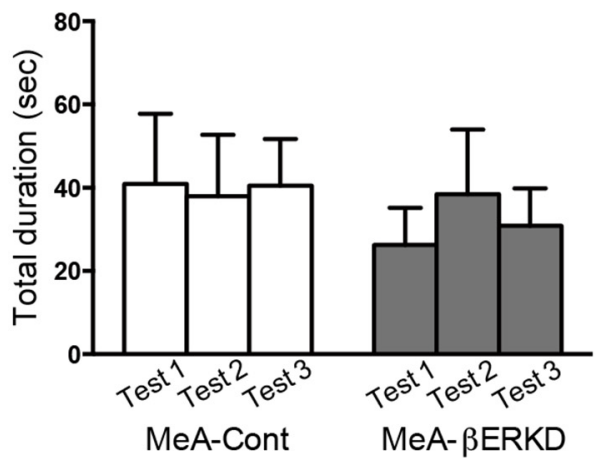

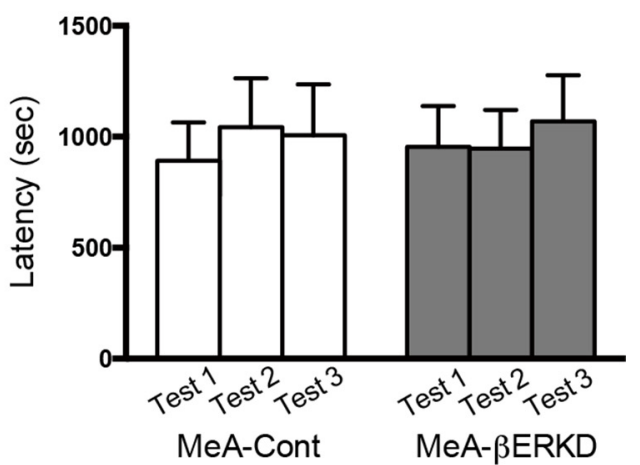

C
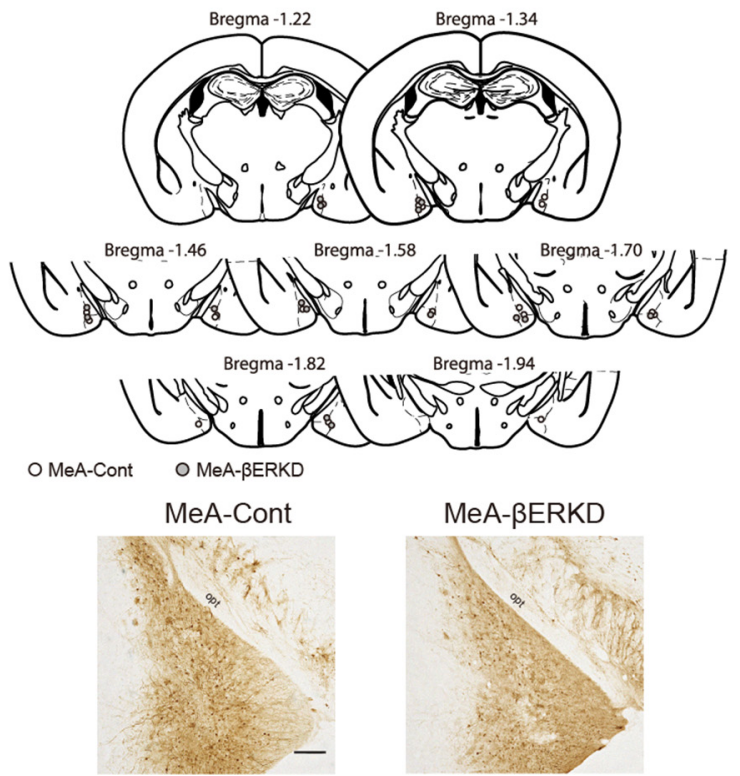

Bregma -1.94
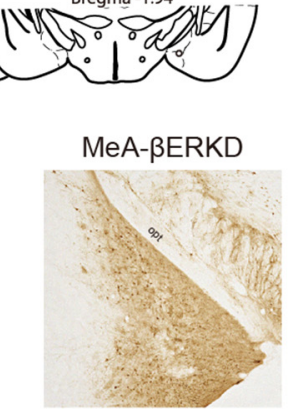

D

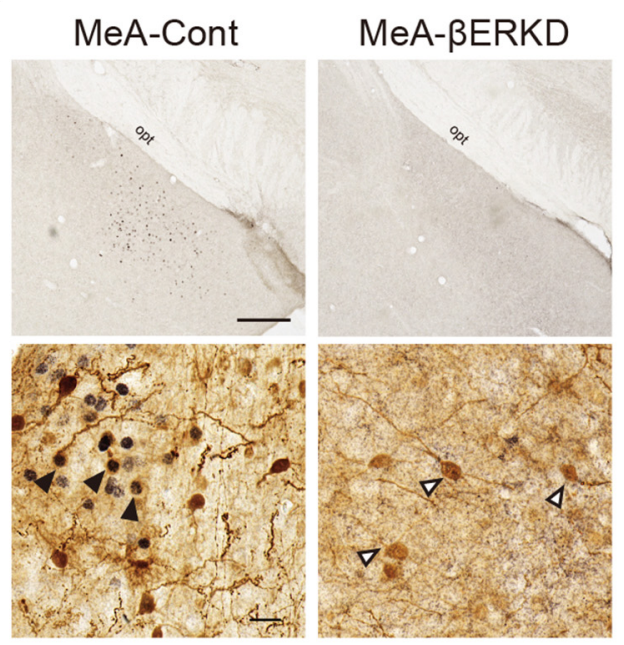

Figure 3. Effects of prepubertal silencing of $E R \beta$ in the MeA on the expression of male sexual and aggressive behaviors in adulthood. A, There were no differences between the MeA-Cont and MeA- $\beta$ ERKD groups in the number of mounts (left), intromissions (middle), or latency to the first mount (right). $\boldsymbol{B}$, There were no differences between the MeA-Cont and MeA- $\beta$ ERKD groups in the duration (left) or number (right) of aggressive bouts. All behavioral data in $\boldsymbol{A}$ and $\boldsymbol{B}$ are presented as mean + SEM. $\boldsymbol{C}$, Histological diagrams depicting the placement of the injection needle tip for each mouse in the MeA-Cont (open circles) and MeA- $\beta$ ERKD (solid circles) groups (top), and representative photomicrographs of MeA sections with singleimmunohistochemical staining for GFP (bottom ; at bregma -1.82). Scale bar, $200 \mu \mathrm{m}$. opt, optic tract. $\boldsymbol{D}$, Representative photomicrographs of MeA sections with single-immunohistochemical staining for $E R \beta$ (top; at bregma -1.94), and MeA sections with double-immunostaining for GFP and $\mathrm{ER} \beta$ (bottom). Number of ER $\beta$-immunoreactive cells in the targeted site was greatly reduced in the $\beta$ ERKD group compared with the control group. Scale bars: top, $200 \mu \mathrm{m}$; bottom, $20 \mu \mathrm{m}$. Bottom, Black 
continued

arrowheads indicate ER $\beta$ and GFP double-immunoreactive cells and white arrowheads indicate immunoreactive cells only for GFP.

processes for the regulation of male sexual behavior. The present finding provides evidence that $\operatorname{ER} \beta$ may also play a role in masculinization of the neural network of aggressive behavior and its site-specificity. Furthermore, an increased number of studies have now shown the importance of pubertal period for brain organization, in addition to classically known perinatal period (Schulz et al., 2004; Sisk and Foster, 2004; Sisk, 2015). A recent study has reported that $\mathrm{ER} \alpha$ in the MeA may play a role in masculinizing action of testosterone during pubertal period (Sano et al., 2015). In this study, it is also reported that $\mathrm{ER} \alpha$ expression in GFP-immunopositive cells at the target brain site was silenced by $5 \mathrm{~d}$ after AAV injection on P21. Because we used vectors with the same conformation, it is likely that $\mathrm{ER} \beta$ expression was successfully reduced before the mice reached pubertal onset. Together, the present finding is the first demonstration indicating that $\operatorname{ER} \beta$ may also participate in pubertal organizational action of testosterone. Molecular mechanisms of ER $\beta$-mediated organizational action of testosterone, however, remains to be elucidated in future studies.
In male mice that reached adult age, injection of AAVshRNA in the MPOA to knockdown ER $\alpha$ (Sano et al., 2013) or $E R \beta$ had a minimal effect on the expression of aggressive behavior. Because gonadally intact male mice were used as experimental animals in both studies, signaling of endogenous testosterone remained unaffected other than $\mathrm{ER} \alpha$ or $\mathrm{ER} \beta$ in the targeted area. Although it is possible that in the fully developed adult brain, two types of ERs may compensate functions of knocked down ER gene, it is likely that ER in the MPOA may not be involved in the regulation of aggressive behavior by activational action of testosterone in adult male mice.

\section{Role of ER $\beta$ in the MeA in the regulation of sexual and aggressive behavior}

Prepubertal treatment with AAV-shER $\beta$ did not alter sexual and aggressive behavior in adulthood (Experiment 1). As expected from this finding, mice treated with AAVshER $\beta$ in adult showed equivalent levels of sexual and aggressive behavior as control mice (Experiment 3). These results suggest that $\operatorname{ER} \beta$ may not be responsible

A
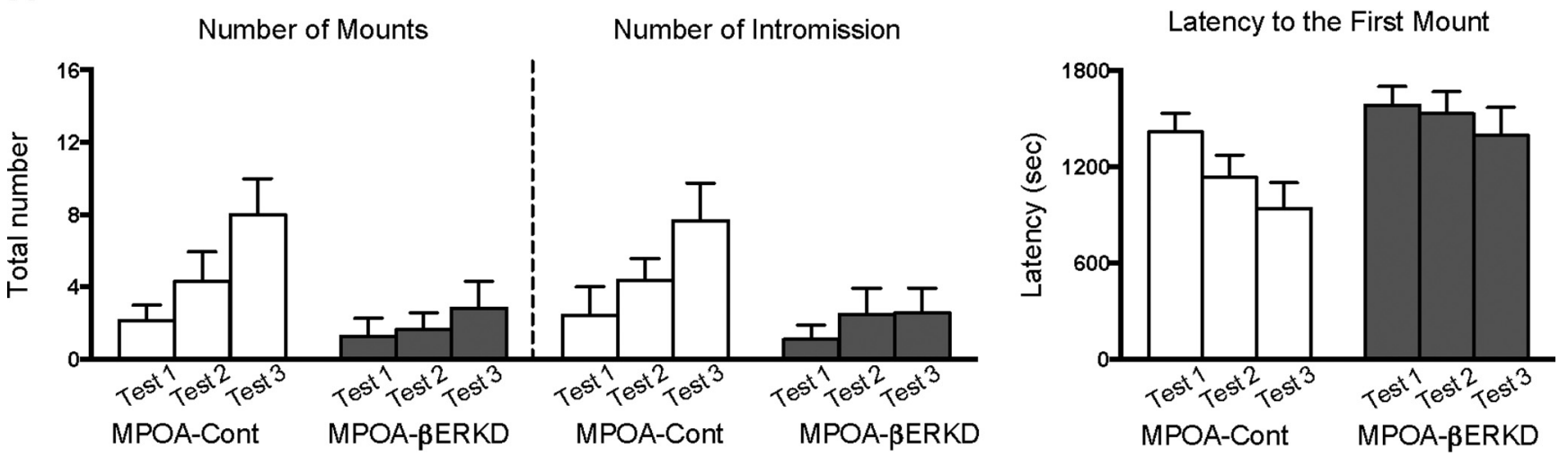

B

Number of Aggressive Bouts

Duration of Aggressive Bouts
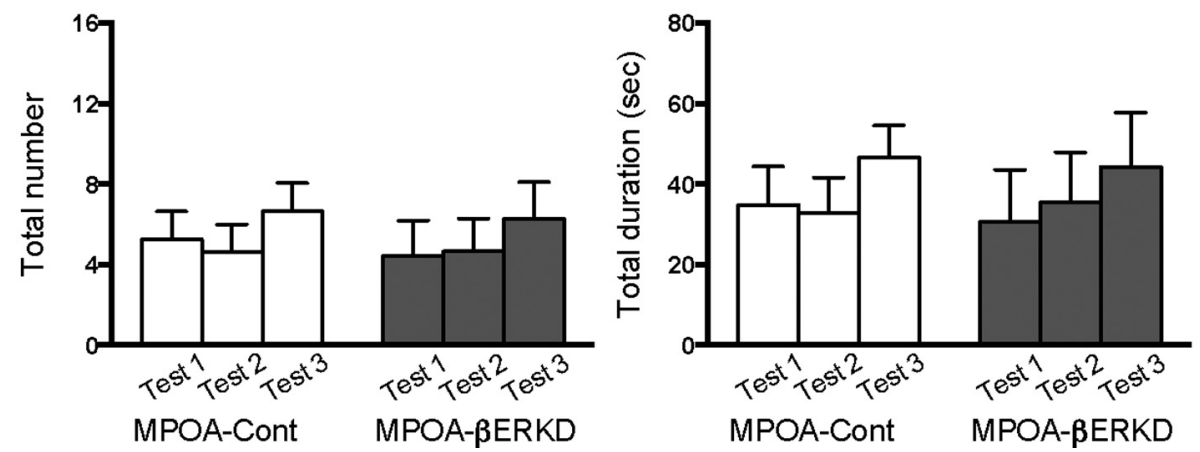

Figure 4. Effects of $\beta E R K D$ in the MPOA in adulthood on male sexual and aggressive behaviors. $\boldsymbol{A}$, There was no difference between the MPOA-Cont and MPOA- $\beta$ ERKD groups in the number of mounts (left), intromissions (middle), or latency to the first mount (right). $\boldsymbol{B}$, There was no difference between the MPOA-Cont and MPOA- $\beta$ ERKD groups in the duration (left) or number (right) of aggressive bouts. All behavioral data are presented as mean + SEM. 

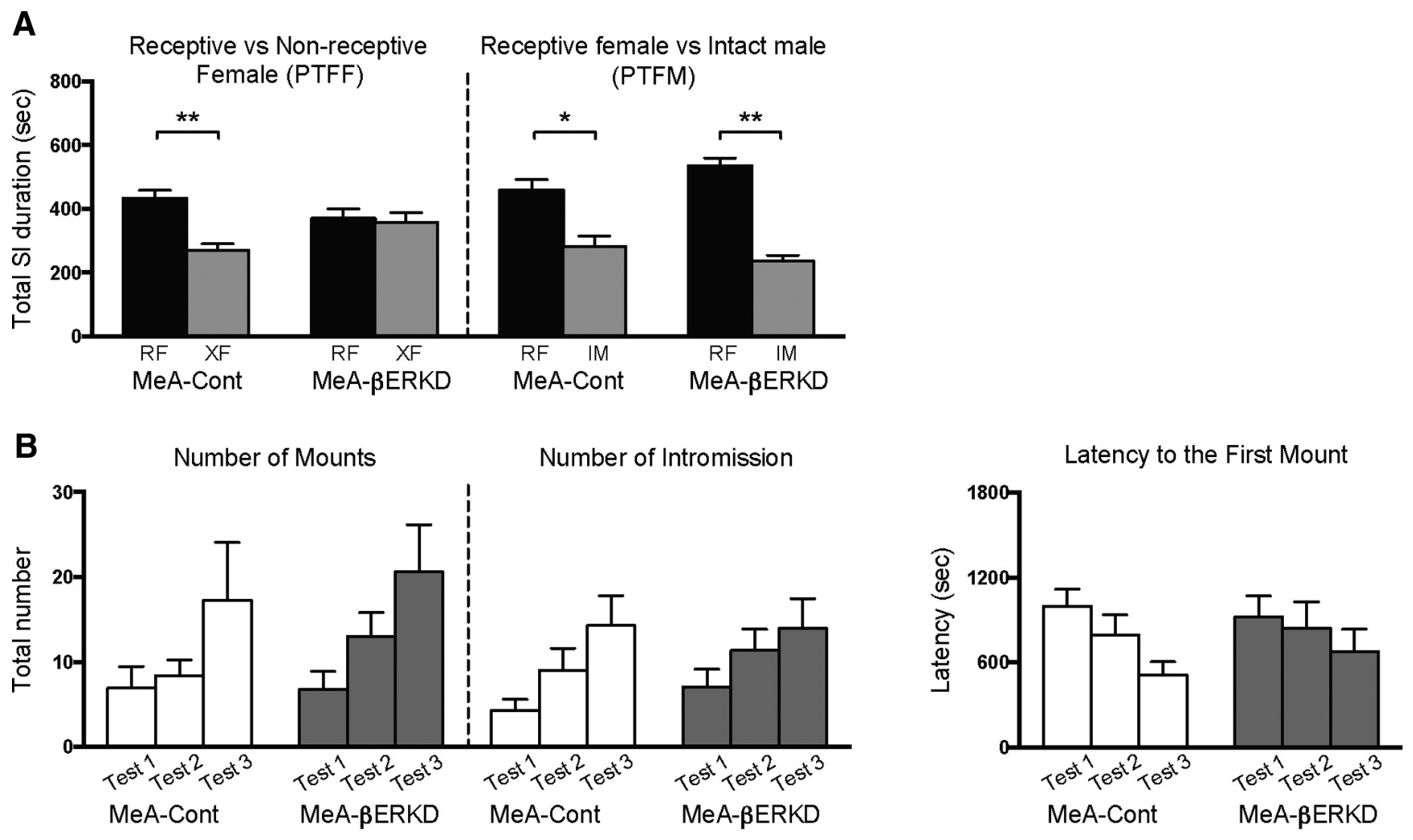

C Number of Aggressive Bouts

Duration of Aggressive Bouts
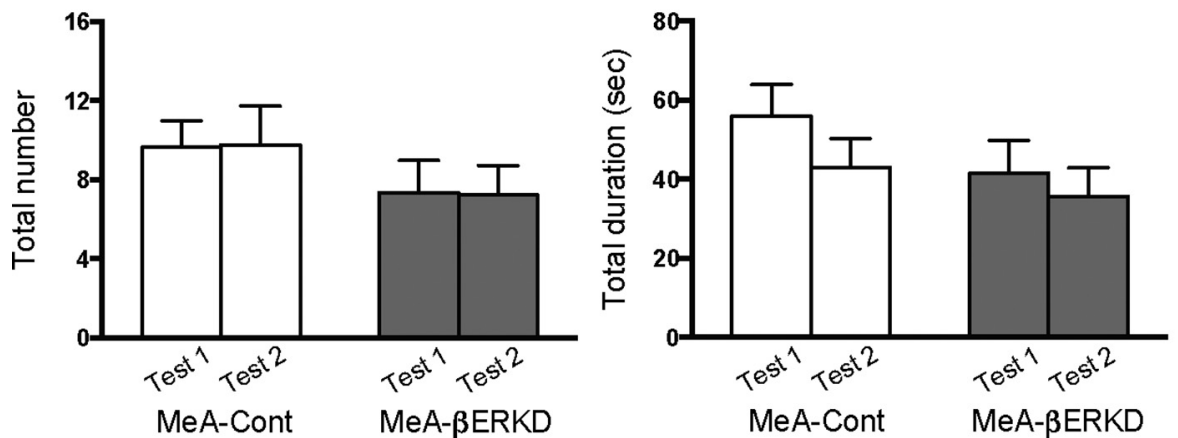

Figure 5. Effects of $\beta E R K D$ in the MeA in adulthood on male sexual preference and sexual and aggressive behaviors. $\boldsymbol{A}$, In PTFF tests, mice in the MeA-Cont group showed longer SI duration toward a receptive female (vs toward a nonreceptive female mouse) but mice in the MeA- $\beta$ ERKD group failed to do so (left). Both of the MeA-Cont and MeA- $\beta$ ERKD groups showed longer SI duration toward a receptive female in PTFM tests (vs toward a male mouse; right; $* p<0.05, * * p<0.01$ ). $\boldsymbol{B}$, There were no differences between the $\mathrm{MeA}-\mathrm{Cont}$ and MeA- $\beta$ ERKD groups in the number of mounts (left), intromissions (middle), or latency to the first mount (right). $\boldsymbol{C}$, There were no differences between the MeA-Cont and MeA- $\beta$ ERKD groups in the duration (left) or number (right) of aggressive bouts. All behavioral data are presented as mean + SEM.

for either organizational or activational action of testosterone in the MeA. However, because we used corncob bedding, which has been reported to contain phytoestrogens (Landeros et al., 2012; Trainor et al., 2013), it is still possible that regardless of AAV treatment, all mice used in the present study may have been exposed estrogenic stimulation enough to partially organize neural circuitry before AAV injection on P21. If this is the case, we cannot completely rule out a possibility of the involvement of $E R \beta$ in organizational action of testosterone in the MeA. This needs to be addressed in the future studies.
In site-specific ER $\alpha$ knockdown mice, it is also reported that $\mathrm{ER} \alpha$ in the MeA may not be involved in activational action of testosterone in the regulation of sexual and aggressive behavior (Sano et al., 2013) although it is essential for organizational action (Sano et al., 2015). MeA is known to be one of the critical brain regions for the induction of male sexual and aggressive behaviors (Vochteloo and Koolhaas, 1987; Kondo, 1992; Newman, 1999). In this brain region, aromatization to estradiol is essential for facilitation of these behaviors by testosterone (Wood, 1996; Unger et al., 2015). The present findings in $\beta E R K D$ 
mice in conjunction with those in $\alpha$ ERKD mice (Sano et al., 2013) suggest that estradiol stimulation through either $\mathrm{ER} \alpha$ or $\mathrm{ER} \beta$ may be sufficient for induction of sexual and aggressive behavior in male mice. In contrast, a recent study in male rats reported that stimulation of both $\mathrm{ER} \alpha$ and $\mathrm{ER} \beta$ might be necessary for induction of sexual behavior, because MeA site-specific implant of either $\mathrm{ER} \alpha$ or ER $\beta$-specific agonist failed to restore sexual behavior in gonadectomized male rats systemically injected with dihydrotestosterone (Russell et al., 2012). It should be noted, however, in this study any ERs other than those in the MeA were not activated.

Given the fact that ER $\beta$ silencing did not alter the expression of sexual and aggressive behaviors, we further examined the effects of $A A V$-shER $\beta$ treatment on sexual preference. The MeA receives direct projections from main and accessory olfactory systems and sends social information to the hypothalamic nuclei including the MPOA and VMN, which are involved in the performance of male sexual and aggressive behaviors (Baum, 2009). In male rats, local lesions in the MeA disrupted sexual preference of receptive female over nonreceptive female rats (Kondo and Sachs, 2002). Recently, it is also reported that MeA lesions in male rats disrupt preference of receptive over nonreceptive females without affecting preference of a receptive female over an intact male (Dhungel et al., 2011). In the present study, we found that lack of $E R \beta$ in the MeA eliminated sexual preference between receptive female and nonreceptive females tested by the PTFF paradigm. During sexual preference tests with the PTFM paradigm, on the other hand, both $\beta E R K D$ and control groups showed clear preference toward a receptive female mouse over a gonadally intact male. Using soiled beddings as stimuli, it is also reported that global ER $\beta$ knockout male mice show normal preference toward receptive female odor over intact male odor (Kudwa et al., 2005). Collectively, these findings suggest that $E R \beta$ in the $\mathrm{MeA}$ is necessary for discrimination of receptivity states of female mice, but not discrimination of females from males. Along this line, it should also be noted that in both PTFF and PTFM tests, total SI duration exhibited toward two stimulus mice was not different between two treatment groups. This finding suggests that $\mathrm{ER} \beta$ knockdown in the MeA did not affect sexual motivation of male mice, consistent with the fact that $\beta$ ERKD mice in the present study showed comparable number of mounts and intromissions as control mice during sexual behavior tests, in which only a receptive female mouse was presented. To this end, it is interesting to examine how $\beta$ ERKD mice may respond if receptive and nonreceptive female mice are simultaneously presented in sexual behavior tests.

\section{Conclusion}

The present study provides evidence suggesting pubertal organizational action of ER $\beta$ in the MPOA for full masculinization of the neural network for male aggressive behavior. In the MeA, ER $\beta$ may be involved in information processing about receptivity states of female mice. Collectively, our results suggest that ER $\beta$ in the MPOA and $\mathrm{MeA}$ are involved in the regulation of male social behav- iors in a manner different from that of $\mathrm{ER} \alpha$. In future studies, it is necessary to determine the role played by ER $\beta$ expressed in other brain sites in the social behavior network, including the bed nucleus of stria terminalis, lateral septum, and dorsal raphe nucleus.

\section{References}

Baum MJ (2009) Sexual differentiation of pheromone processing: links to male-typical mating behavior and partner preference. Horm Behav 55:579-588. CrossRef Medline

Coolen LM, Peters HJ, Veening JG (1997) Distribution of Fos immunoreactivity following mating versus anogenital investigation in the male rat brain. Neuroscience 77:1151-1161. Medline

Couse JF, Korach KS (1999) Estrogen receptor null mice: what have we learned and where will they lead us? Endocr Rev 20:358-417. CrossRef Medline

Dhungel S, Urakawa S, Kondo Y, Sakuma Y (2011) Olfactory preference in the male rat depends on multiple chemosensory inputs converging on the preoptic area. Horm Behav 59:193-199. CrossRef Medline

Handa RJ, Ogawa S, Wang JM, Herbison AE (2012) Roles for oestrogen receptor $\beta$ in adult brain function. J Neuroendocrinol 24: 160-173. CrossRef Medline

Hull EM, Lorrain DS, Du J, Matuszewich L, Lumley LA, Putnam SK, Moses J (1999) Hormone-neurotransmitter interactions in the control of sexual behavior. Behav Brain Res 105:105-116. Medline

Hull EM, Meisel RL, Sachs BD (2002) Male sexual behavior. In: Hormones, brain and behavior (Pfaff DW, Arnold AP, Fahrbach SE, Etgen AM, Rubin RT, eds), pp 3-137. San Diego: Academic/ Elsevier.

Hull EM, Rodriguez-Manzo G (2009) Males sex behavior. In: Hormones, brain and behavior, Ed 2 (Pfaff DW, Arnold AP, Fahrbach SE, Etgen AM, Rubin RT, eds), pp 5-66. San Diego: Academic/ Elsevier.

Kavaliers M, Devidze N, Choleris E, Fudge M, Gustafsson JÅ, Korach KS, Pfaff DW, Ogawa S (2008) Estrogen receptors alpha and beta mediate different aspects of the facilitatory effects of female cues on male risk taking. Psychoneuroendocrinology 33:634-642. CrossRef Medline

Kondo $Y$ (1992) Lesions of the medial amygdala produce severe impairment of copulatory behavior in sexually inexperienced male rats. Physiol Behav 51:939-943. Medline

Kondo Y, Sachs BD (2002) Disparate effects of small medial amygdala lesions on noncontact erection, copulation, and partner preference. Physiol Behav 76:443-447. Medline

Kudwa AE, Bodo C, Gustafsson JÅ, Rissman EF (2005) A previously uncharacterized role for estrogen receptor: defeminization of male brain and behavior. Proc Natl Acad Sci U S A 102:4608-4612. CrossRef Medline

Landeros RV, Morisseau C, Yoo HJ, Fu SH, Hammock BD, Trainor BC (2012) Corncob bedding alters the effects of estrogens on aggressive behavior and reduces estrogen receptor- $\alpha$ expression in the brain. Endocrinology 153:949-953. CrossRef

Mitra SW, Hoskin E, Yudkovitz J, Pear L, Wilkinson HA, Hayashi S, Pfaff DW, Ogawa S, Rohrer SP, Schaeffer JM, McEwen BS, Alves SE (2003) Immunolocalization of estrogen receptor $\beta$ in the mouse brain: comparison with estrogen receptor $\alpha$. Endocrinology 144: 2055-2067. CrossRef Medline

Nelson RJ, Trainor BC (2007) Neural mechanisms of aggression. Nat Rev Neurosci 8:536-546. CrossRef Medline

Newman S (1999) The medial extended amygdala in male reproductive behavior. Ann N Y Acad Sci 242-257. CrossRef

Nomura M, Durbak L, Chan J, Smithies O, Gustafsson JÅ, Korach KS, Pfaff DW, Ogawa S (2002) Genotype/age interactions on aggressive behavior in gonadally intact estrogen receptor $\beta$ knockout ( $\beta$ ERKO) male mice. Horm Behav 41:288-296. CrossRef Medline 
Nomura M, Korach KS, Pfaff DW, Ogawa S (2003) Estrogen receptor $\beta(E R \beta)$ protein levels in neurons depend on estrogen receptor $\alpha$ $(\mathrm{ER} \alpha)$ gene expression and on its ligand in a brain region-specific manner. Mol Brain Res 110:7-14. CrossRef

Nomura M, Akama KT, Alves SE, Korach KS, Gustafsson JA, Pfaff DW, Ogawa S (2005) Differential distribution of estrogen receptor (ER) $\alpha$ and $\operatorname{ER} \beta$ in the midbrain raphe nuclei and periaqueductal gray in male mouse: predominant role of $E R \beta$ in midbrain serotonergic systems. Neuroscience 130:445-456. CrossRef Medline

Nomura M, Andersson S, Korach KS, Gustafsson JÅ, Pfaff DW, Ogawa S (2006) Estrogen receptor-beta gene disruption potentiates estrogen-inducible aggression but not sexual behaviour in male mice. Eur J Neurosci 23:1860-1868. CrossRef Medline

Ogawa S, Lubahn DB, Korach KS, Pfaff DW (1997) Behavioral effects of estrogen receptor gene disruption in male mice. Proc Natl Acad Sci U S A 94:1476-1481. Medline

Ogawa S, Washburn TF, Taylor J, Lubahn DB, Korach KS, Pfaff DW (1998) Modifications of testosterone-dependent behaviors by estrogen receptor $\alpha$ gene disruption in male mice. Endocrinology 139:5058-5069. CrossRef Medline

Ogawa S, Chan J, Chester AE, Gustafsson JÅ, Korach KS, Pfaff DW (1999) Survival of reproductive behaviors in estrogen receptor $\beta$ gene-deficient ( $\beta$ ERKO) male and female mice. Proc Natl Acad Sci U S A 96:12887-12892. Medline

Ogawa S, Chester AE, Hewitt SC, Walker VR, Gustafsson JÅ, Smithies O, Korach KS, Pfaff DW (2000) Abolition of male sexual behaviors in mice lacking estrogen receptors $\alpha$ and $\beta$ ( $\alpha \beta$ ERKO). Proc Natl Acad Sci U S A 97:14737-14741.

Oyola MG, Portillo W, Reyna A, Foradori CD, Kudwa A, Hinds L, Handa RJ, Mani SK (2012) Anxiolytic effects and neuroanatomical targets of estrogen receptor- $\beta(E R \beta)$ activation by a selective ER $\beta$ agonist in female mice. Endocrinology 153:837-846. CrossRef Medline

Paredes RG (2003) Medial preoptic area/anterior hypothalamus and sexual motivation. Scand J Psychol 44:203-212. Medline

Patisaul HB, Bateman HL (2008) Neonatal exposure to endocrine active compounds or an ERbeta agonist increases adult anxiety and aggression in gonadally intact male rats. Horm Behav 53:580588. CrossRef Medline

Paxinos G, Franklin KB (2001) The mouse brain in stereotaxic coordinates. San Diego: Academic.

Rissman EF, Wersinger SR, Taylor JA, Lubahn DB (1997) Estrogen receptor function as revealed by knockout studies: neuroendocrine and behavioral aspects. Horm Behav 31:232-243. CrossRef Medline

Russell NV, Ogaga-Mgbonyebi EV, Habteab B, Dunigan Al, Tesfay MA, Clancy AN (2012) Sexual responses of the male rat medial preoptic area and medial amygdala to estrogen II: site specific effects of selective estrogenic drugs. Horm Behav 62:58-66. CrossRef Medline

Sano K, Tsuda MC, Musatov S, Sakamoto T, Ogawa S (2013) Differential effects of site-specific knockdown of estrogen receptor $\alpha$ in the medial amygdala, medial pre-optic area, and ventromedial nucleus of the hypothalamus on sexual and aggressive behavior of male mice. Eur J Neurosci 37:1308-1319. CrossRef

Sano K, Nakata M, Musatov S, Sakamoto T, Tsukahara S, Ogawa S (2015) Pubertal activation of estrogen receptor alpha in the medial amygdala is necessary for the expression of male-type social behavior in adult mice. Soc Neurosci Abst.
Schulz KM, Richardson HN, Zehr JL, Osetek AJ, Menard TA, Sisk CL (2004) Gonadal hormones masculinize and defeminize reproductive behaviors during puberty in the male Syrian hamster. Horm Behav 45:242-249. CrossRef Medline

Shughrue PJ, Lane MV, Merchenthaler I (1997) Comparative distribution of estrogen receptor- $\alpha$ and $-\beta$ mRNA in the rat central nervous system. J Comp Neurol 388:507-525. CrossRef

Shughrue PJ, Merchenthaler I (2001) Distribution of estrogen receptor $\beta$ immunoreactivity in the rat central nervous system. J Comp Neurol 436:64-81. Medline

Sisk CL, Foster DL (2004) The neural basis of puberty and adolescence. Nat Neurosci 7:1040-1047. CrossRef Medline

Sisk CL (2015) Gonadal hormones organize the adolescent brain and behavior. In: Brain crosstalk in puberty and adolescence (Bourguignon JP, Carel JC, Christen Y, eds), pp15-27. Switzerland: Springer.

Snyder MA, Smejkalova T, Forlano PM, Woolley CS (2010) Multiple $\mathrm{ER} \beta$ antisera label in ER $\beta$ knockout and null mouse tissues. J Neurosci Methods 188:226-234. CrossRef Medline

Tomihara K, Soga T, Nomura M, Korach KS, Gustafsson JÅ, Pfaff DW, Ogawa S (2009) Effect of ER-beta gene disruption on estrogenic regulation of anxiety in female mice. Physiol Behav 96:300306. CrossRef Medline

Trainor BC, Takahashi EY, Campi KL, Florez SA, Greenberg GD, Laman-Maharg A, Laredo SA, Orr VN, Silva AL, Steinman MQ (2013) Sex differences in stress-induced social withdrawal: independence from adult gonadal hormones and inhibition of female phenotype by corncob bedding. Horm Behav 63:543-550. CrossRef Medline

Tsuda MC, Yamaguchi N, Nakata M, Ogawa S (2014) Modification of female and male social behaviors in estrogen receptor beta knockout mice by neonatal maternal separation. Front Neurosci 8:274. CrossRef Medline

Unger EK, Burke KJ, Yang CF, Bender KJ, Fuller PM, Shah NM (2015) Medial amygdalar aromatase neurons regulate aggression in both sexes. Cell Rep 10:453-462. CrossRef Medline

Veening JG, Coolen LM, de Jong TR, Joosten HW, de Boer SF, Koolhaas JM, Olivier B (2005) Do similar neural systems subserve aggressive and sexual behaviour in male rats? Insights from c-Fos and pharmacological studies. Eur J Pharmacol 526:226-239. CrossRef Medline

Vochteloo JD, Koolhaas JM (1987) Medial amygdala lesions in male rats reduce aggressive behavior: interference with experience. Physiol Behav 41:99-102. Medline

Walf AA, Frye CA (2006) A review and update of mechanisms of estrogen in the hippocampus and amygdala for anxiety and depression behavior. Neuropsychopharmacology 31:1097-111. CrossRef Medline

Weiser MJ, Foradori CD, Handa RJ (2008) Estrogen receptor beta in the brain: from form to function. Brain Res Rev 57:309-320. CrossRef Medline

Wersinger SR, Sannen K, Villalba C, Lubahn DB, Rissman EF, De Vries GJ (1997) Masculine sexual behavior is disrupted in male and female mice lacking a functional estrogen receptor alpha gene. Horm Behav 32:176-183. CrossRef Medline

Wood R (1996) Estradiol, but not dihydrotestosterone, in the medial amygdala facilitates male hamster sex behavior. Physiol Behav 59:833-841. Medline 